\title{
絶滅危惧種ヤツガタケトウヒの木材特性の半径方向の変動*1
}

\author{
久保島吉貴 $* 2$, 勝木俊雄 $* 2$, 明石浩司 $* 3$, 山下香菜 $* 2$, \\ 鈴木養樹*2, 外崎真理雄*2
}

\section{Radial Variations in Wood Properties of a Threatened Species, Picea koyamae*1}

\author{
Yoshitaka KubojIma*2, Toshio Katsuki*2, Kohji AkAshi*3, \\ Kana Yamashita*2, Youki SuZuKI ${ }^{* 2}$ and Mario TonOSAKI*2
}

\begin{abstract}
A tree of Picea koyamae, a threatened conifer felled by a typhoon, was obtained and various properties of its wood were investigated to understand the value for lumber. Measurements were taken of grain angle and color. Mechanical properties were measured with static bending, impact bending and compression tests. Since Picea spp. is used for musical instruments, vibration tests were also undertaken. The results were as follows: 1) The grain was an S-helix, and the grain angle decreased toward the bark. 2) Mechanical properties did not change remarkably, but they increased partly toward the bark. Mechanical properties around the pith differed from those in other parts. 3) Mechanical properties were similar to those of other Picea spp. except the compressive Young's modulus in the Rdirection. 4) Brightness index was high. 5) Although Picea koyamae has superior properties among those mentioned above, many knots exist at intervals of 300 to $400 \mathrm{~mm}$. Hence, pruning is very impor-
\end{abstract} tant.

Keywords : mechanical properties, brightness index, Picea koyamae, pruning, threatened species.

絶滅危惧種ヤッガタケトウヒ（Picea koyamae Shiras.）の木材価值を確認するため木材特性を 検討した。試験体には台風による風倒木を用いた。纎維傾斜角, 静的曲げ特性, 衝撃曲げ特性, 圧縮特性抢よび材色を測定した。さらにトウヒ属が楽器に用いられることを考え，振動特性も測 定した。以下の結果を得た。1）木理は主に $\mathrm{S}$ 螺旋で, 繊維傾斜角は髄付近で大きく, 樹皮へ向 かって減少した。2）半径方向の力学特性の変動は, 髄付近が他の部位と異なる場合が多く, 概 略あまり大きくなかったが，一部樹皮に向かって増大する場合が認められた。3）力学特性は半 径方向圧縮ヤング率を除き他のトウヒと大差なかった。4）白色度は他の白いと思われた 8 樹種 よりも大きく, トドマッと同程度であった。5）これらの優れた特徴を持つものの，節が300$400 \mathrm{~mm}$ 間隔で輪生するので施業（枝打ち）がポイントとなると考えられた。

*1 Received September 2, 2009; accepted December 2, 2009. 本研究の一部は第59回日本木材学会大会 (2009年 3 月，松本）において発表した。

*2 森林総合研究所 Forestry and Forest Products Research Institute, Tsukuba 305-8687, Japan

*3 飯田市美術博物館 Iida City Museum, Iida 3950034, Japan

\section{1. 緒言}

ヤツガタケトウヒ（Picea koyamae Shiras.）は, 胸高直径 $80 \mathrm{~cm}$, 樹高 $34 \mathrm{~m}$ にも達するマツ科トウヒ 属の常緑の高木で, 長野県と山梨県の亜高山帯から 山地帯上部に遺存的に残されているだけであり, そ の個体数は極めて少ない。環境省のレッドデータブ ックでは絶滅危惧 Ib 類としてリストされている。 地史的な観点から見ると現在の気候では衰退しつつ ある種として捉えられるが, 個々の自生地の状況を 
考えるとカラマツの植林など人為による悪影響も無 視出来ない。

ヤツガタケトウヒはドイツトウヒときわめて近縁 な種と考えられており, 高い木材価值が推測される。 実際に 40 年生のヤツガタケトウヒ人工林も造林され ており, 将来的には木材資源としての利用が期待さ れている1。

保全は材の利用と両輪となって上手く回る。例え ば，ニュージーランドの代表的な輸出木材ラジアタ パインが好例である。ラジアタパインは北米のサン フランシスコ太平洋岸のごく限られた地域にしか自 然分布していないが，木材利用のために自生地外で 植栽され続ければ，絶滅と無縁であると思われる。 ヤツガタケトゥヒも適切に造林して多方面で利用さ れれば, 将来的に絶滅は回避されるかも知れな

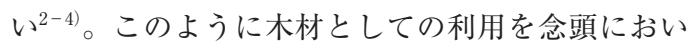
た場合，力学特性を得ておくことは必要不可欠であ る。

今回, 長野県産ヤツガタケトウヒを入手したので, 木材価値を確認するため, 纎維傾斜角, 静的曲げ特 性, 衝撃曲げ特性, 圧縮特性㧍よび材色を測定した。 さらにトゥヒ属が楽器に用いられることを考え, 振 動特性も測定した。

\section{2. 実験}

\section{1 試験体}

長野県富士見町の八ケ岳の西岳国有林 1310 林班 （カラマッ沢） 産， 樹齢約120年，胸高直径530 $\mathrm{mm}$, 樹高 $30 \mathrm{~m}$ のヤツガタケトウヒの台風による 風倒木を試験体に用いた。目視で節が $30-40 \mathrm{~cm}$ 間 隔で輪生することが確認された（Fig. 1)。地上高 4-8 m に位置し, 最大直径を含む板より, 纎維傾斜 角測定用, 静的曲げ試験用, 衝撃曲げ試験用および 振動試験用試験体を作製した。静的曲げ試験用試験 体からフィブリル傾角測定用試験体を採取した。

静的曲げ試験用，衝撃曲げ試験用および振動試験 用試験体を色彩試験用および木口面の光学顕微鏡観 察にも用いた。目視で材色が白い部類に入ると思わ れたので，比較のために，スギ（Cryptomeria japonica D. Don 辺材), ヒノキ (Chamaecyparis obtusa Endl. 辺材), トドマッ (Abies sachalinensis Mast. 心辺材区別せず), シトカスプルース（Picea sitchensis Carr. 心辺材区別せず)，エゾマッ（Picea jezoensis Carr. 辺材)，アカエゾマツ (Picea glehnii Mast. 心辺材区別せず)，アカマツ (Pinus desiflora Sieb. et Zucc. 辺材) おょびキリ (Paulownia tomentosa Steud. 心辺材区別せず）を材色が白い材
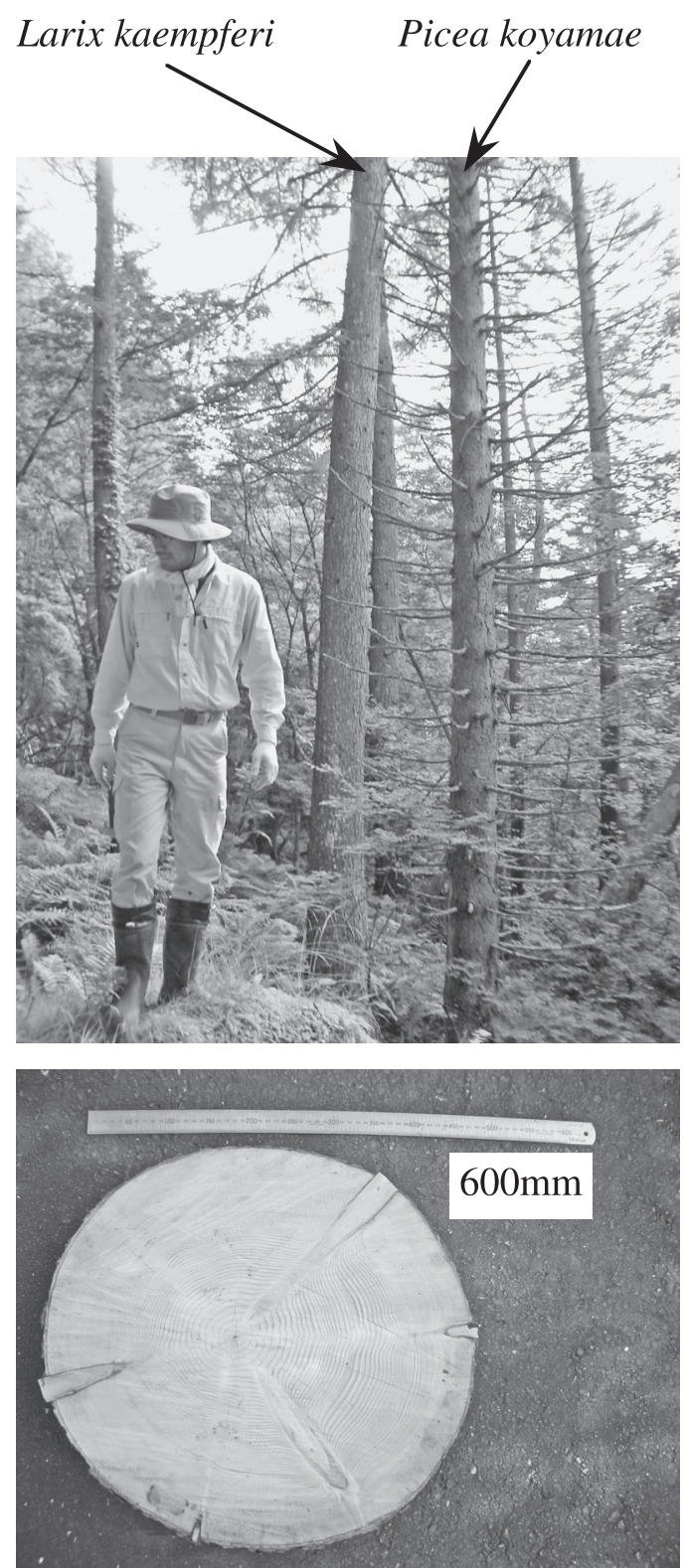

Fig. 1. A tree and a cross section of Picea koyamae. Note: Maximum diameter is $428 \mathrm{~mm}$.

\section{として用いた。}

\section{2 繊維傾斜角}

幅 $95 \mathrm{~mm}(\mathrm{~T})$, 高さ $110 \mathrm{~mm}(\mathrm{~L})$ の板の直径に 沿って鉈で L 方向に割って纎維傾斜角を測定し $た^{5,6)}$ 。

\section{3 静的曲げ試験}

$20 \mathrm{~mm}(\mathrm{R}) \times 20 \mathrm{~mm}(\mathrm{~T}) \times 320 \mathrm{~mm}(\mathrm{~L})$ の寸法の試 験体を作製し，スパン $280 \mathrm{~mm}$ ，クロスヘッドスピ 
ード $5 \mathrm{~mm} / \mathrm{min}$ で材料試験機（島津製作所 AUTOGRAPH AG-5000B）を用いて 3 点曲げ静的 曲げ試験を行い, 静的曲げヤング率, 静的曲げ比例 限度, 静的曲げ強度を求めた。試験体には温度 $20^{\circ} \mathrm{C}$, 相対湿度 $65 \%$ で調湿されたものを用いた。

\section{4 衝撃曲げ試験}

$20 \mathrm{~mm}(\mathrm{R}) \times 20 \mathrm{~mm}(\mathrm{~T}) \times 300 \mathrm{~mm}(\mathrm{~L})$ の寸法の試 験体を作製し，スパンを $240 \mathrm{~mm}$ とし，シャルピー 型衝撃試験機（前川試験機製作所 TYPE A10, 容 量98.1 J）を用い，衝撃曲げ試験を行い，衝撃曲げ 吸収エネルギーを測定した。試験体には温度 $20^{\circ} \mathrm{C}$, 相対湿度 $65 \%$ で調湿されたものを用いた。

\section{5 両端自由撓み振動試験}

$20 \mathrm{~mm}(\mathrm{R}) \times 10 \mathrm{~mm}(\mathrm{~T}) \times 260 \mathrm{~mm}(\mathrm{~L})$ および 25 $\mathrm{mm}(\mathrm{L}) \times 10 \mathrm{~mm}(\mathrm{~T}) \times 110 \mathrm{~mm}(\mathrm{R})$ の寸法の試験体 を作製し両端自由撓み振動試験を行った。試験体を 打撃することによって励起し共振周波数を得, 自由 振動曲線を描いた。ヤング率と剪断弾性係数を Timoshenko の撓み振動理 論7) に基づく GoensHearmon の回帰法 ${ }^{8}{ }^{89}$ より算出した。自由振動曲線 の振幅比より対数減衰率を求め, その值を $\pi$ で除し て損失正接とした。試験体には温度 $20^{\circ} \mathrm{C}$, 相対湿度 65\%で調湿されたものを用いた。

\section{6 圧縮試験}

$20 \mathrm{~mm}(\mathrm{R}) \times 20 \mathrm{~mm}(\mathrm{~T}) \times 40 \mathrm{~mm}(\mathrm{~L}), 20 \mathrm{~mm}(\mathrm{~L})$ $\times 20 \mathrm{~mm}(\mathrm{~T}) \times 40 \mathrm{~mm}(\mathrm{R}), \quad 20 \mathrm{~mm}(\mathrm{~L}) \times 20 \mathrm{~mm}(\mathrm{R})$ $\times 40 \mathrm{~mm}(\mathrm{~T})$ の寸法の試験体を作製し， 2 軸ゲー ジ（共和電業 KFG-2-120-D16-11L3M2S）を20 $\mathrm{mm} \times 40 \mathrm{~mm}$ の 4 面に貼付（接着剂：共和電業 CC-35）した。前出の材料試験機を用いてクロスへ ッドスピード $1 \mathrm{~mm} / \mathrm{min}$ で加力し, デー夕を記録 計 (東京測器研究所TDS-303および取り込みソ フト TDS-7130）に取り込み, 縦圧縮ヤング率, 縦圧縮比例限度, ならびに縦圧縮強度, 横圧縮ヤン グ率および横圧縮比例限度, およびポアソン比を求 めた。試験体には温度 $20^{\circ} \mathrm{C}$, 相対湿度 $65 \%$ で調湿さ れたものを用いた。

\section{7 フィブリル傾角}

試験体中央部の年輪の晚材部から厚さ $15 \mu \mathrm{m}$ の板 目面切片を作製し，シュルツ液で処理，水洗および 脱酸し，アルコールで脱水した。切片をスライドガ ラス上に取り, ヨウ素ヨウ化カリウム液を滴下し, 続いて $60 \%$ 硝酸を滴下し，カバーガラスを乗せ $た^{10)}$ 。

傾斜角度は, 撮影された写真においてヨウ素結晶 の傾斜に沿って測定線を引き, 仮道管の軸方向の線 との間の角度を分度器で読み取った。測定数は 1 サ
ンプル当たり約 30 本であった。

\section{8 木口面の光学顕微鏡観察}

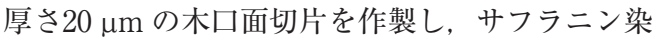
色して, アルコールシリーズで脱水, キシレンに置 換した後, カナダバルサムで封入し, 光学顕微鏡で 観察した。

\section{9 色彩試験}

色彩色差計（コニカミノルタ CR-410）を用い, センサを柾目面に当て, $\mathrm{L}^{*} \mathrm{a} \mathrm{a}^{*}$ *表色系の指数を求 めた。ヤツガタケトウヒ以外の樹種の寸法は $25 \mathrm{~mm}$ (R) $\times 5 \mathrm{~mm}(\mathrm{~T}) \times 300 \mathrm{~mm}$ であった。 $\mathrm{L}^{*} \mathrm{a}^{*} \mathrm{~b}^{*}$ 表色 系とは，X，Y，Z の測定値を基にマンセル表色（人 の知覚に対応した心理的な表色）に近い色相関を表 現しょうとして考え出された国際照明委員会 (CIE) の表色系である ${ }^{11)}$ 。ここで， L*は明度指数で，大 きいほど白いことを示す。 $\mathrm{a}^{*}$ および $\mathrm{b}$ *はクロマテ

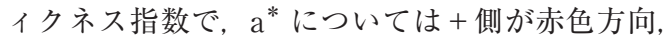

一側が緑色方向を示し, b*については+側が黄色 方向，一側が青色方向をそれぞれ示す。ヤツガタケ トウヒでは30体，他の樹種では10-15体用いた。試 験体には温度 $20^{\circ} \mathrm{C}$, 相対湿度 $65 \%$ で調湿されたもの を用いた。

\section{3. 結果および考察}

Fig. 2-6 に半径方向の各木材特性の変動を示す。 髄からの距離 $d>0$ がより半径の大きい側を示す。 3.1 半径方向の取り方による物性の相違

Fig. 3-6 において髄からの距離 $d$ が正の側での力

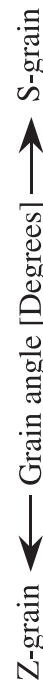

10

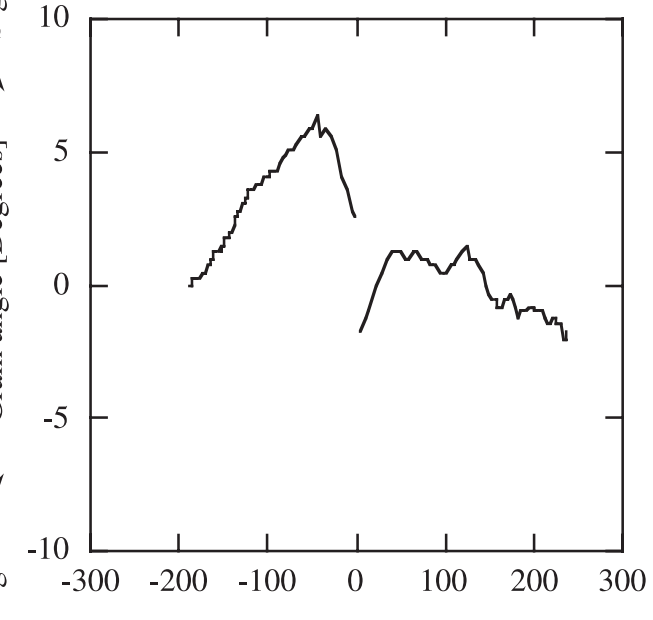

Distance from pith [mm]

Fig. 2. Radial variation of grain angle. 


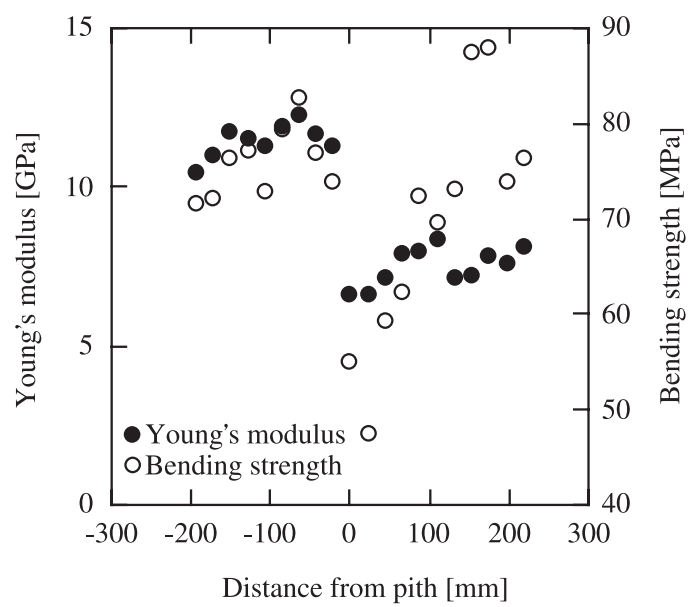

Fig. 3. Radial variation of static bending properties.

Notes: Distance from pith $d<0$ and $d>0$ means normal wood and compression wood, respectively.

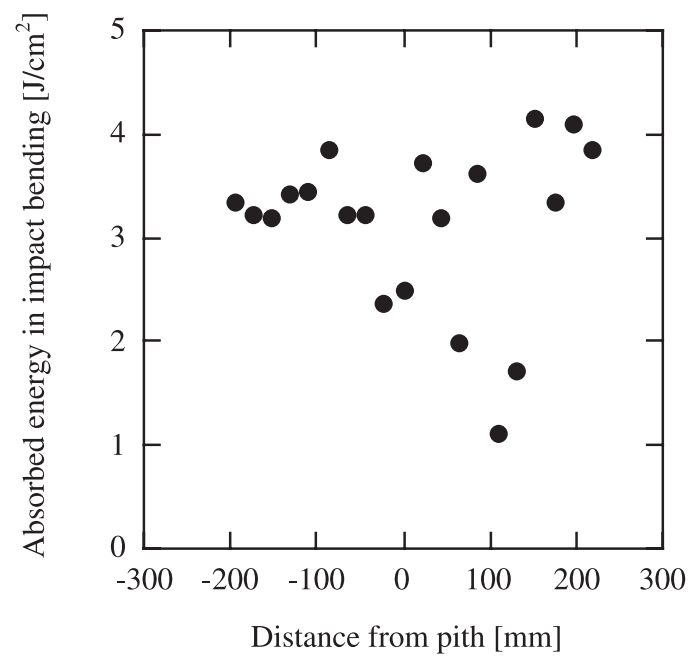

Fig. 4. Radial variation of impact bending properties. Note: Refer to Fig. 3.

学特性は, 負の側よりも, L 方向ヤング率（静的曲 げ，圧縮，振動)，縦圧縮強度が小さく，損失正接 が大きかった。そこでフィブリル傾角を検討すると， $d>0$ で $d<0$ よりも大きかった（Fig. 7)。さら に, $d>0$ で木口面の細胞形状が丸味を帯びた (Fig. 8)。以上より $d>0$ に圧縮あて材の存在が考 えられる。このため上記の力学特性の傾向が得られ たと推察される。また，衝撃曲げ吸収エネルギーに もフィブリル傾角の大きさが影響する可能性が考え られる。さらに, 横圧縮試験では $d$ の正負による 違いが鮮明には見られなかったので, フィブリル傾
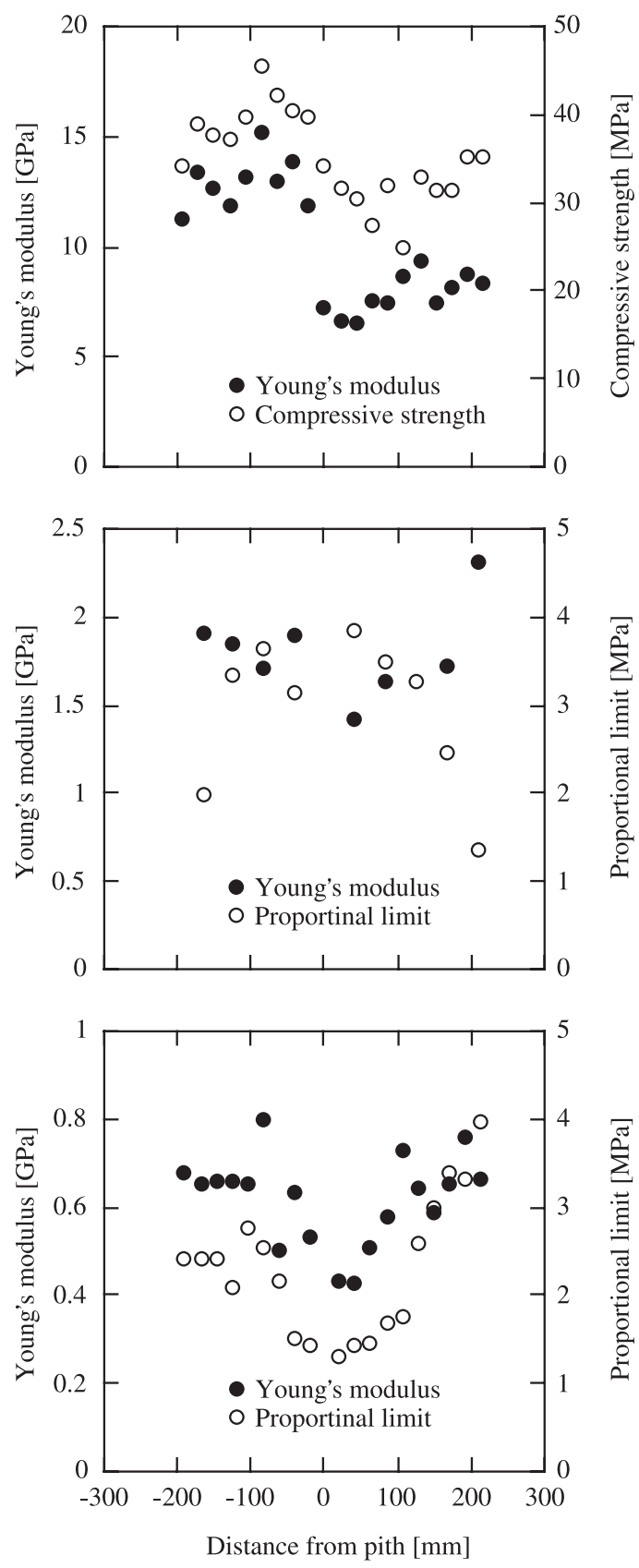

Fig. 5. Radial variation of compressive properties.

Notes: Top: longitudinal direction; Middle: radial direction; Bottom: tangential direction. Refer to Fig. 3.

角は R, T方向には L方向ほどには影響しないと考 えられる。これは, 荷重方向と繊維走向のなす角が 大きいと圧縮強度や圧縮ヤング率の変化が小さいこ と ${ }^{12)}$ から類推される。 

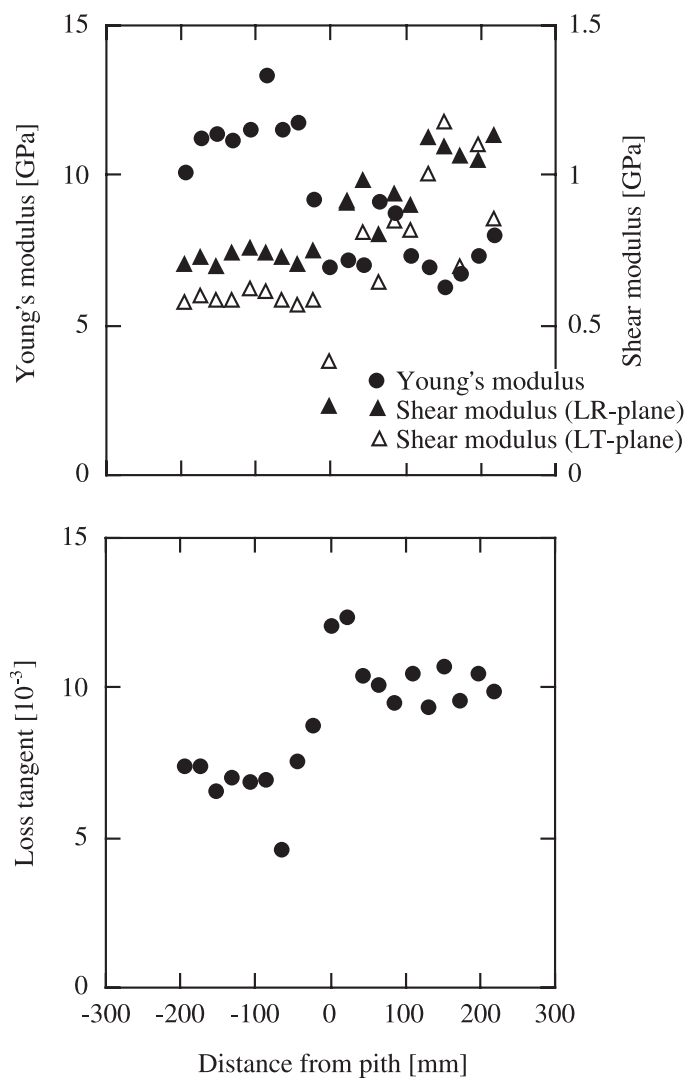

Fig. 6. Radial variation of vibration properties. Note: Refer to Fig. 3.

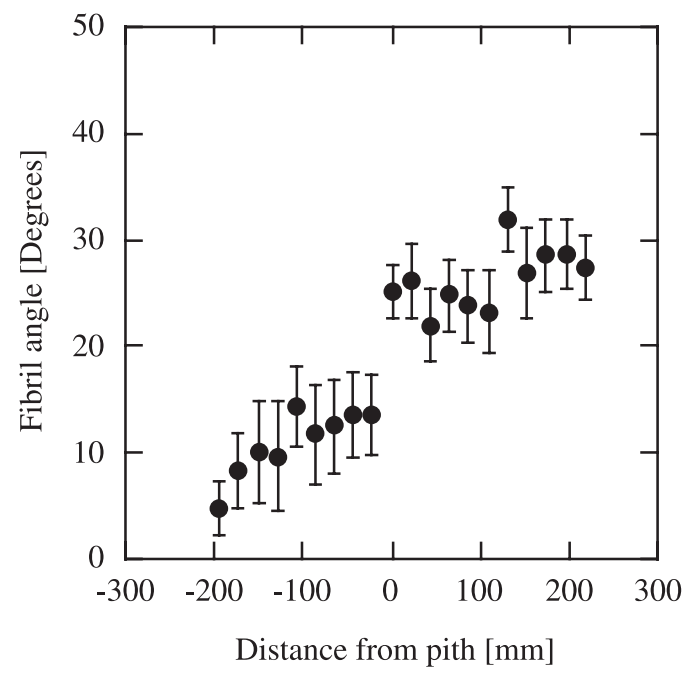

Fig. 7. Radial variation of fibril angle. Note: Refer to Fig. 3.

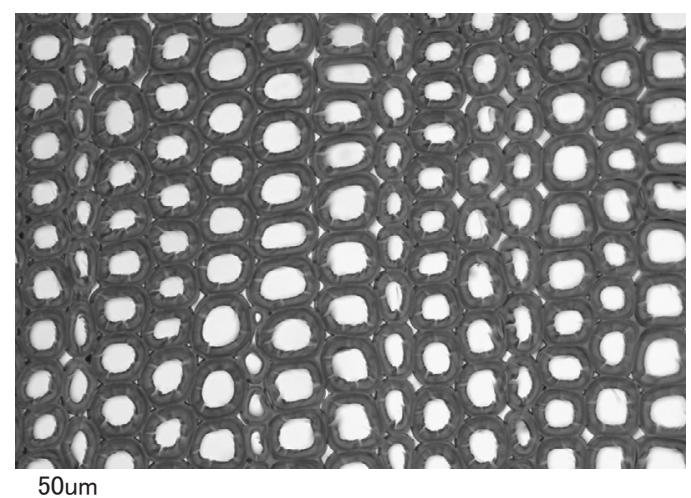

Fig. 8. Optical microscope photograph of the cross section of the specimen used for the static bending test.

Note: Distance from pith is $153 \mathrm{~mm}$ (Fig. 3).

剪断弾性係数（LR面, LT 面) は圧縮あて材の ない側の $d<0$ のほうが小さかった。このことに ついて考察する。剪断弾性係数と繊維傾斜角 $\theta$ に関 する Jenkin の式は下記1)で表される。実験には緎 維傾斜のない試験体を用いたので䋊維傾斜の項 $\theta$ に フィブリル傾角を用いる。

$$
\left.\frac{1}{G_{\theta}}=\left(\frac{1}{E_{\mathrm{x}}}+\frac{1}{E_{\mathrm{y}}}+\frac{2 v_{\mathrm{xy}}}{E_{\mathrm{x}}}\right) \sin ^{2} 2 \theta+\frac{1}{G_{\mathrm{xy}}} \cos ^{2} 2 \theta 1\right)
$$

ここで, 添え字 $\mathrm{x}$ はL方向, $\mathrm{y}$ は R またはT方向を 示し, $v$ はポアソン比を示す。

この式から剪断弾性係数は $0^{\circ} \leqq \theta \leqq 90^{\circ}$ の範囲で $\theta=45^{\circ}$ に関して対称であり, $0^{\circ} \leqq \theta \leqq 45^{\circ}$ の範囲抒 よび $45^{\circ} \leqq \theta \leqq 90^{\circ}$ の範囲では単調増加または単調減 少する。そこで $\theta=0^{\circ}$ での值と $\theta=45^{\circ}$ での值を比 較する。

$$
G_{45}-G_{0}=\frac{E_{\mathrm{x}} E_{\mathrm{y}}}{\left(1+2 v_{\mathrm{xy}}\right) E_{\mathrm{y}}+E_{\mathrm{x}}}-G_{\mathrm{xy}}
$$

本実験では弾性定数は Table 1 のようになるの で, $G_{45}-G_{0}$ の值は LR 面で0.15-0.69, LT 面で0.11 および 0.13 となり，いずれも正であるため，すなわ ち $0^{\circ} \leqq \theta \leqq 45^{\circ}$ に扔いて $G$ は $\theta$ に対して単調増加す るため, いずれもフィブリル傾角が小さい方が剪断 弾性係数は小さくなる。このようにフィブリル傾角 は剪断弾性係数の増大に寄与する場合があると考え られる。なお, 剪断弾性係数がフィブリル傾角と正 の相関を持つことがヤツガタケトウヒに特有の特徵 かどうかは今後の検討課題である。

\section{2 半径方向の変動}

圧縮あて材を含まない $d<0$ の部分における半 径方向の物性の変動について述べる。 
木理は主に $\mathrm{S}$ 螺旋で, 繊維傾斜角は䯣付近で大き く，樹皮へ向かって減少した（Fig. 2)。この傾向は 繊維傾斜角を詳細に検討した山下らの結果 ${ }^{13)}$ と同 様であった。静的曲げヤング率, 静的曲げ強度, 衝 撃曲げ吸収エネルギー, 縦圧縮ヤング率および縦圧 縮強度は䯣付近では小さいほかは変動は小さかった (Fig. 3-5)。半径方向横圧縮ヤング率は変動が小さ く, 半径方向圧縮比例限度は樹皮付近で減少した (Fig. 5)。接線方向圧縮ヤング率および接線方向圧 縮比例限度は樹皮へ向かい増大した（Fig. 5)。振動 試験によるL方向ヤング率および剪断弾性係数 (LR 面，LT面）は髄付近で小さいほかは変動が小さか った（Fig. 6)。損失正接（L方向）は髄付近で大き いほかは半径方向の変動は小さかった（Fig. 6)。

\section{3 他樹種との木材特性の比較}

圧縮あて材材を含む側 $d>0$ を除く力学特性の 平均值（標準偏差）を他のトウヒ（振動試験結果に 関してはシトカスプルースと比較しそれ以外はエゾ マツ）と合わせて Table 1 に示す。力学特性はおお むね他のトウヒと大差なく, 密度と平均年輪幅との 相関を調べると, 静的曲げヤング率, 縦圧縮ヤング 率および縦圧縮強度が密度と高い相関があった以外 は相関関係は認められなかった。

このように, ヤツガタケトウヒ材の力学特性がシ トカスプルース材およびエゾマツ材と同様であった ので，シトカスプルース材およびエゾマツ材と同様 に建築材, 家具材およびピアノ響板やヴァイオリン 甲板などの楽器用材にも利用出来る可能性があ る ${ }^{16)}$ 。ただし，ヤツガタケトウヒ材はこれらの優れ た特徴を持つものの, Fig. 1 のように節が300$400 \mathrm{~mm}$ 間隔で輪生するので施業（枝打ち）がポイ ントとなると考えられた。

また材色は他の白いと思われた材と比較してもよ り白く,トドマツと同程度であった (Table 2)。尚, 種々の樹種の材色に関する一覧は基太村 ${ }^{17)}$ によっ て報告されているが，今回のデー夕はそれらと異な る。これは使用した装置が刺激值直読方法によって いるためと考えられる。

\section{4. 結 論}

現在絶滅危惧種に指定されているものの，実際に 人工林が造林されており, 将来的には木材資源とし ての利用が期待されているヤツガタケトウヒの木材 価值を確認するため, 纎維傾斜角, 静的曲げ特性, 衝撃曲げ特性, 圧縮特性, 振動特性および色彩特性 を測定した。結果は以下のとおりである。

\section{1.木理は主に S 螺旋で, 繊維傾斜角は髄付近で大}

Table 1. Wood properties of Picea koyamae.

\begin{tabular}{|c|c|c|}
\hline & P. koyamae & Other Picea spp. \\
\hline$\rho\left[\mathrm{g} / \mathrm{cm}^{3}\right]$ & $0.410(0.0326)^{\mathrm{a})}$ & $0.43^{\mathrm{b})}$ \\
\hline$E_{\mathrm{sb}}[\mathrm{GPa}]$ & $11.48(0.50)$ & $9.0^{\mathrm{b})}$ \\
\hline$\sigma_{\mathrm{sb}}[\mathrm{MPa}]$ & $76.00(3.44)$ & $70^{\mathrm{b})}$ \\
\hline$W_{\mathrm{ib}}\left[\mathrm{J} / \mathrm{cm}^{2}\right]$ & $3.25(0.37)$ & $4.5^{\mathrm{b})}$ \\
\hline$E_{\text {cL }}[\mathrm{GPa}]$ & $12.90(1.13)$ & $10.7^{\mathrm{c})}$ \\
\hline$E_{\mathrm{cR}}[\mathrm{GPa}]$ & $1.77(0.33)$ & $0.71^{\mathrm{c})}$ \\
\hline$E_{\text {ст }}[\mathrm{GPa}]$ & $0.80(0.12)$ & $0.43^{c)}$ \\
\hline$\sigma_{\mathrm{cL}}[\mathrm{MPa}]$ & $39.49(3.02)$ & $35^{\mathrm{b})}$ \\
\hline$P_{\mathrm{cR}}[\mathrm{MPa}]$ & $2.88(0.89)$ & $1.9^{\mathrm{b})}$ \\
\hline$P_{\text {ст }}[\mathrm{MPa}]$ & $2.20(0.43)$ & $1.2^{\mathrm{b})}$ \\
\hline$v_{\text {LR }}$ & $0.40(0.058)$ & $0.37^{\mathrm{c}}$ \\
\hline$v_{\mathrm{LT}}$ & $0.45(0.022)$ & $0.47^{c)}$ \\
\hline$v_{\mathrm{RL}}$ & $0.11(0.028)$ & $0.029^{c)}$ \\
\hline$v_{\mathrm{RT}}$ & $0.69(0.036)$ & $0.43^{c)}$ \\
\hline$v_{\mathrm{TL}}$ & $0.038(0.0088)$ & $0.020^{c)}$ \\
\hline$v_{\text {TR }}$ & $0.31(0.039)$ & $0.25^{\mathrm{c})}$ \\
\hline$E_{\mathrm{L}}^{\mathrm{TGH}}[\mathrm{GPa}]$ & $11.25(1.06)$ & $10.7^{\mathrm{c})}$ \\
\hline$E_{\mathrm{R}}{ }^{\mathrm{TGH}}[\mathrm{GPa}]$ & $1.03(0.12)$ & $0.71^{c)}$ \\
\hline$G_{\mathrm{LR}}[\mathrm{GPa}]$ & $0.73(0.020)$ & $0.500^{c)}$ \\
\hline$G_{\mathrm{LT}}[\mathrm{GPa}]$ & $0.59(0.017)$ & $0.618^{\mathrm{c})}$ \\
\hline$G_{\mathrm{RT}}[\mathrm{GPa}]$ & $0.034(0.0065)$ & $0.023^{\mathrm{c})}$ \\
\hline $\tan \delta_{\mathrm{L}}\left[10^{-3}\right]$ & $7.01(1.03)$ & $7.4^{\mathrm{d})}$ \\
\hline $\tan \delta_{\mathrm{R}}\left[10^{-3}\right]$ & $20.22(0.90)$ & $18.0^{\mathrm{d})}$ \\
\hline
\end{tabular}

Note Average (SD); a) : All specimens. Others are specimens in the range of distance from pith $d<0$; b) : P. jezoensis from reference 14) ; c): P. sitchensis from reference 14); d): $P$. sitchensis from reference $15) ; \rho$ : Air dried density. $E_{\mathrm{sb}}$ : Static bending Young's modulus; $\sigma_{\mathrm{sb}}$ : Static bending strength; $W_{\mathrm{ib}}$ : Absorbed energy in impact bending; $E_{\mathrm{cL},}, E_{\mathrm{cR}}$ and $E_{\mathrm{cT}}$ : Compressive Young's modulus in the $\mathrm{L}, \mathrm{R}$ and $\mathrm{T}$ directions, respectively; $\sigma_{\mathrm{cL}}$ : Compressive strength in the L-direction; $P_{\mathrm{cR}}, P_{\mathrm{cT}}$ : Compressive proportional limit in the $\mathrm{R}$ and $\mathrm{T}$-directions, respectively; $v_{\mathrm{LR}}, v_{\mathrm{LT}}$, $v_{\mathrm{RL}}, v_{\mathrm{RT}}, v_{\mathrm{TL}}$ and $v_{\mathrm{TR}}$ : Poisson's ratio; $E_{\mathrm{L}}{ }^{\mathrm{TGH}}$ and $E_{\mathrm{R}}{ }^{\mathrm{TGH}}$ : Young's moduli obtained by vibration test in the Land R-directions, respectively; $G_{\mathrm{LR}}, G_{\mathrm{LT}}, G_{\mathrm{RT}}$ : Shear moduli of the LR-, LT- and RT-planes, respectively; $\tan \delta_{\mathrm{L}}$ and $\tan \delta_{\mathrm{R}}$ : loss tangent in the $\mathrm{L}^{-}$and $\mathrm{R}-$ directions, respectively.

きく，樹皮へ向かって減少した。

2. 半径方向の力学特性の変動は, 䯣付近が他の部 位と異なる場合が多く，概略あまり大きくなかっ たが，一部樹皮に向かって増大する場合が認めら れた。

3. 力学特性は半径方向圧縮ヤング率を除き他のト ウヒと大差なかった。

4. 白色度は他の白いと思われた材よりも大きく, トドマツと同程度であった。 
Table 2. Color values of various woods.

\begin{tabular}{l|c|c|c}
\hline \hline & $\mathrm{L}^{*}$ & $\mathrm{a}^{*}$ & $\mathrm{~b}^{*}$ \\
\hline Picea koyamae $(\mathrm{HS})$ & $70.17(3.52)$ & $15.20(1.36)$ & $35.98(2.42)$ \\
\hline Picea jezoensis $(\mathrm{S})$ & $48.67(2.10)$ & $17.25(0.94)$ & $28.16(2.15)$ \\
\hline Picea glehnii (HS) & $62.31(1.21)$ & $20.12(0.43)$ & $38.67(1.43)$ \\
\hline Picea sitchensis (HS) & $52.87(7.53)$ & $21.68(1.56)$ & $29.76(5.50)$ \\
\hline Pinus desiflora (S) & $62.32(3.02)$ & $20.78(1.51)$ & $39.96(2.46)$ \\
\hline Abies sachalinensis (HS) & $67.80(1.11)$ & $14.77(0.76)$ & $29.76(0.91)$ \\
\hline Cryptomeria japonica (S) & $54.30(3.75)$ & $14.39(0.79)$ & $28.47(1.90)$ \\
\hline Chamaecyparis obtusa (S) & $54.20(2.75)$ & $14.06(1.73)$ & $28.46(1.09)$ \\
\hline Paulownia tomentosa (HS) & $56.73(2.12)$ & $9.22(0.78)$ & $22.73(1.15)$ \\
\hline
\end{tabular}

Note Average (SD); HS: Heartwood and sapwood; S: Sapwood

5. これらの優れた特徴を持つものの, 節が300$400 \mathrm{~mm}$ 間隔で輪生するので施業（枝打ち）がポ イントとなると考えられた。

\section{謝辞}

本研究を遂行するに当たり，中部森林管理局元島 清人氏ならびに特定非営利活動法人森の座西村智幸 氏, 島根大学総合理工学部吉原浩准教授抒よび北海 道立林産試験場大崎久司氏の御協力を賜りました。 また，中部森林管理局南信森林管理署より試験用丸 太を提供して戴きました。御礼申し上げます。

\section{文献}

1）勝木俊雄 : 林木の育種 207, 17-19 (2003).

2）金谷整一：かごしまウッディテック・フォー ラム 21, 32-35 (2002).

3）金谷整一：木材工業 64(5), 210-215 (2009).

4）久保島吉貴:木材工業 63(11), 579-581 (2008).

5）三上 進, 長坂寿俊: 林試研報 276, 1-22 (1975).

6) Kubojima, Y., Kanetani, S., Fujiwara, T., Suzuki, Y., Tonosaki, M., Yoshimaru, H., Ikegame, H. : J. Wood Sci. 54, 443-450 (2008).
7) Timoshenko, S. P.: Phil. Mag. 6 Ser. 41, 744746 (1921).

8) Goens, E.: Annal. der Phys. 5(6), 649-678 (1931).

9) Hearmon, R. F. S. : Brit. J. Appl. Phys. 9, 381-388 (1958)

10）佐伯 浩, 徐 永吉, 藤田 稔：木材学会誌 35, 786-792 (1989).

11）増田 稔：“日本木材学会研究分科会報告書 木材の科学と利用技術 II, 1. 自動計測の基礎 と応用”, 日本木材学会編, 日本木材学会, 東京, 1991, p. 56.

12）北原覚一：“木材物理”, 森北出版, 東京, 1966, pp. 133-134.

13) Yamashita, K., Katsuki, T., Akashi, K., Kubojima, Y.: Bull. For. For. Prod. Res. Inst. 9, 19-29 (2010).

14）“木材工業ハンドブック”, 森林総合研究所監 修, 丸善, 東京, 2004, pp. 135-195.

15) Kubojima, Y., Wada, M., Suzuki, Y., Tonosaki, M. : Wood Sci. Technol. 35, 503-515 (2001).

16）“木材工業ハンドブック”, 森林総合研究所監 修, 丸善, 東京, 2004, pp. 12-20.

17）基太村洋子：林試研報 347, 203-239（1987）. 